\title{
Histopathological effects of zinc oxide nanoparticles prepared by Vaccinium arctostaphylos ethanolic fruit extract on liver and pancreas of diabetic rats
}

\author{
Abolfazl Bayrami ${ }^{1}$, Shadi Parvinroo ${ }^{2}$, Shima Rahim Pouran ${ }^{3}$, Aziz Habibi Yengjah ${ }^{4}$, Farid Moammadi \\ Arvanagh $^{2}$, Mahdi Bayrami $^{5}$ \\ 1. Associate Professor, Department of Biology, Faculty of Science, University of Mohagheghe Ardabili, Ardabil, Iran., \\ (Corresponding Author), Email: a_bayrami@uma.ac.ir, Tel:045-31505187. ORCID ID: 0000-0001-7002-8605. \\ 2.M.Sc. in Animal Physiology, Department of Biology, Faculty of Science, University of Mohagheghe Ardabili, Ardabil, \\ Iran. ORCID ID: 0 00-0003-3505-890X. \\ 3.Ph.D. of Environmental Health, Social Determinants of Health Research Center, Ardabil University of Medical Sciences, \\ Ardabil, Iran. ORCID ID: 0000-0002-1891-5204. \\ 4.Professor, Department of Chemistry, Faculty of Science, University of Mohagheghe Ardabili, Ardabil, Iran. Orcid ID: \\ $0 \cdot 00-0002-4543-2793$. \\ 5.Doctor of Veterinary Medicine, Department of Veterinary Medicine, Faculty of Veterinary Medicine, Azad University of \\ Tabriz, Tabriz, Iran. ORCID ID: 000-0002-7782-6594
}

\begin{abstract}
Background and Aim: The vast applications of nanotechnology in various fields including medicine, brings about the necessity to investigate the in vivo side effects of these materials. On this basis, we investigated the potential anti-diabetic activity of nanoparticles (NPs) along with toxicological effects on liver and pancreas tissue.

Materials and Methods: In this excremental research after preparation of $\mathrm{ZnO}$ nanoparticles and their characterization with SEM, EDX and TEM, 30 rats were studied in 6 groups of 5 each. The groups included 1- Healthy control 2- Diabetic control 3- Diabetic - Insulin (10 $\mathrm{U} / \mathrm{kg})$ 4- Diabetic - Cranberry (150 mg/kg) 5- Diabetic-ZnO (8 mg/kg) 6- Diabetic-ZnO + extract $(8 \mathrm{mg} / \mathrm{kg})$. Diabetes was induced with alloxan monohydrate via intraperitoneal injection $(170 \mathrm{mg} / \mathrm{kg})$. Rats were treated intraperitoneal for 16 days and every four days examined for blood glucose levels, at the end of the treatment period, the liver and pancreatic tissues were analyzed by hematoxylin-eosin staining. Data were analyzed using two-way ANOVA and Tukey post hoc tests in SPSS.

Results: The analysis of nanoparticles revealed the capping of organic constituents on the surface of the biological nanoparticles. The assessment of serum samples displayed a significant decrease in blood glucose levels in the group that was treated by NPs prepared by extract when compared to that of the diabetic control group $(p \leq 0 / 05)$. Histopathological analysis did not show any damages to the studied organs.

Conclusion: The results obtained in the present study revealed that the bio-synthesized nanoparticles not only significantly decreased the blood glucose level of diabetic rats but also had no toxic effects on the liver and pancreas tissues at the concentrations used in this study.
\end{abstract}

Keywords: Cranberry; Liver, Nanotechnology, Pancreas, Therapeutic, Toxicity

Received: Sep 1, $2020 \quad$ Accepted: Oct 21, 2020

How to cite the article: Abolfazl Bayrami, Shadi Parvinroo, Shima Rahim Pouran, Aziz Habibi Yengjah, Farid Moammadi Arvanagh, Mahdi Bayrami. Histopathological effects of zinc oxide nanoparticles prepared by Vaccinium arctostaphylos ethanolic fruit extract on liver and pancreas of diabetic rats. SJKU 2021;26(2):1224.

Copyright (C) 2018 the Author (s). Published by Kurdistan University of Medical Sciences. This is an open access article distributed under the terms of the Creative Commons Attribution-Non Commercial License 4.0 (CCBYNC), where it is permissible to download, share, remix, transform, and buildup the work provided it is properly cited. The work cannot be used commercially without permission from the journal 


\section{مطالعه اثرات بافتى نانو ذرات زيستى اكسيد روى تهيه شده با عصاره اتانولى ميوه قره}

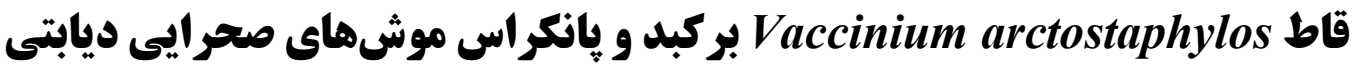

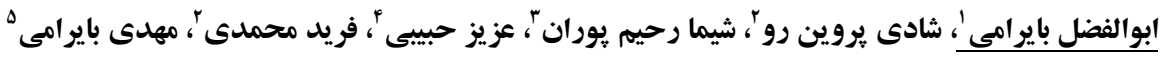

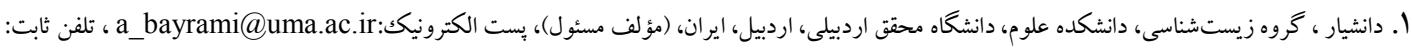

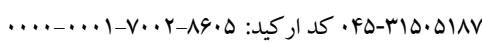

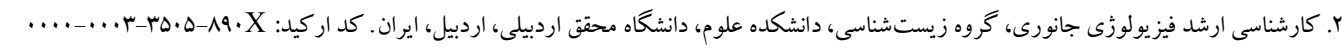

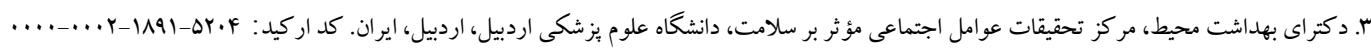

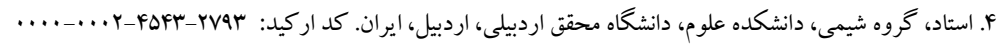

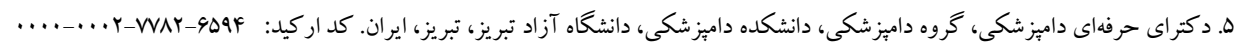

جكيله

زمينه و هدف: گسترش نانو تكنولوزى در زمينهاى مختلف از جمله يزشكى نياز به بررسى عوارض جانبى اين مواد در محيط زنده را ايجاد مى كند؛ لذا در اين يزوهش با توليد نانو داروى زيستى ضمن بررسى اثر ضد ديابتى آن، اثرات سميتى احتمالى بر بافت كبد و يانكراس نيز مطالعه شد. مواد و روشها: در اين مطالعه تجربى يس از تهيه نانو ذرات زيستى و غير زيستى اكسيد روى و مشخصه يابى آنها با

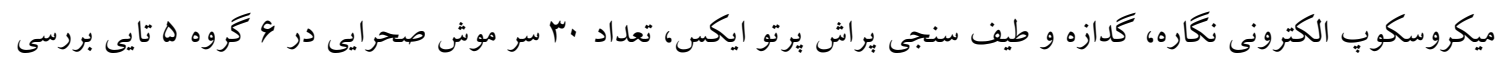

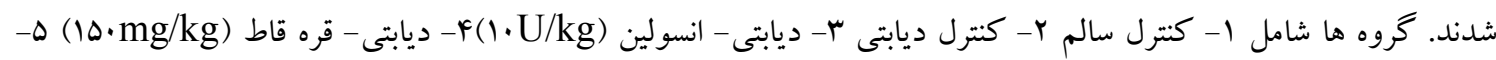

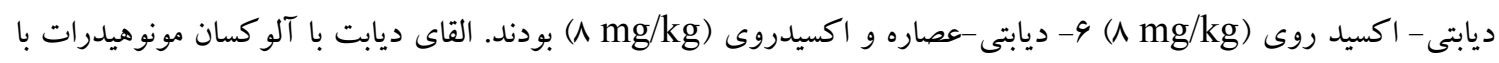
تزريق زيرصفاقى (IV.mg/kg) انجام شد. موش ها 19 روز به صورت زير صفاقى تحت تيمار قرار گرفته و ضمن بررسى ميزان قند خون، در پايان دوره بافت هاى كبد و پانكراس با رنگك آميزى هماتو كسيلين -ائوزين مورد مطالعه قرار كرفت. يافته هاى حاصل

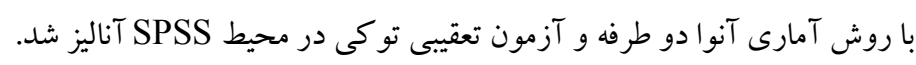
يافته ها: آناليز نانو ذرات بيانكر اتصال گروههاى آلى بر سطح نانو ذرات آن ها بوده است. بررسى نمونه هاى سرم تهيه شده حاكى از كاهش معنى دار قند خون در گرووه هاى تيمار شده با نانو داروها نسبت به گروه كنترل ديابتى است (ه •/ > p). بررسى بافتى كبد و پِانكر اس ضايعات بافتى نشان نداد. نتيجه Fيرى: يزوهش حاضر نشان داد كه نانو ذرات زيستى، عليرغم اثرات معنىدار در كاهش قند خون موشهاى ديابتى در

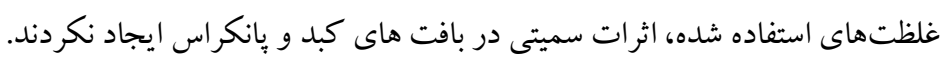
كلمات كليدى: قره قاط، كبد، نانوتكنولوزى، يانكراس، درمانى، سميت وصول مقاله: 99/9/11 اصلاحيه نهايى:99/V/V يذيرش: •ب9/V/T 
عال عالعم اثرات بافتى نانوذرات...

رسـيده آن حساوى سـه آنتوسـيانين اصلى اسـت كـه نشـان مقدمه

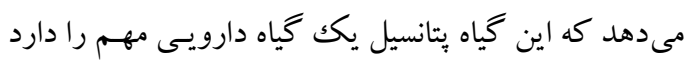

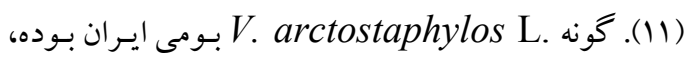
در استانهاى اردبيل، گيلان و مازندران در ارتفاعات مناطق لـانه

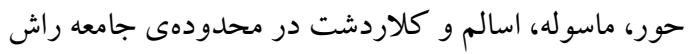
يراكنش دارد (Y) (Y). نام محلى اين گياه قره قاط يا سياه گيله

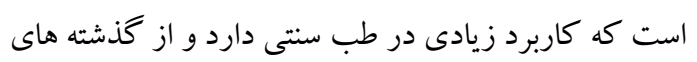

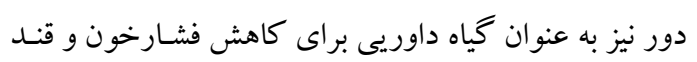
خون استفاده مى شود (سا).

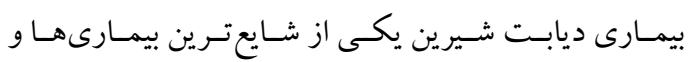
اختلالات متابوليسمى است كه در تمامى كشو رهاى دنيـا در

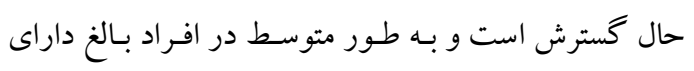

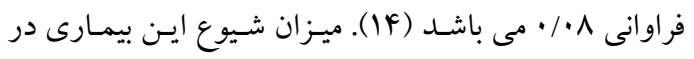

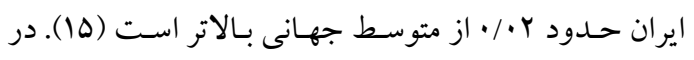

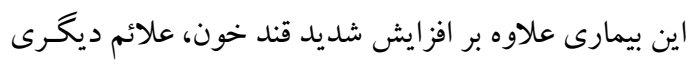

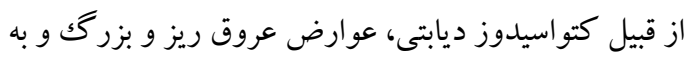

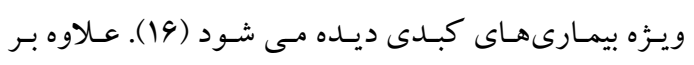

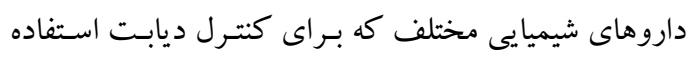

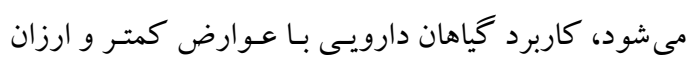

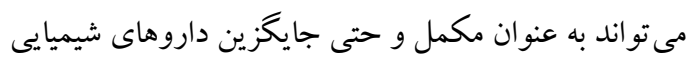
باشد. در جند سـال اخيـر تر كيـبـ علوم جديـــ و سـنتى نيـز درصدد توليد داروهاى جديدى براى كنترل بيمـارى ديابـت است، نانو فناورى، توليد نانو داروها را با اسـتفاده از گياهـان دارويى و در تكميل طب سنتى آغاز كرده و تر كيباتى بسيار مؤثر در كنترل بيمارى ديابت حاصل شده است (F-1). بررسى يافتهاى جديد در خصوص استفاده از نانو ذرات در

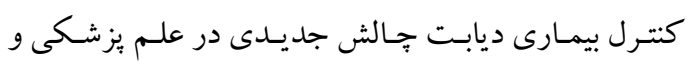
داروسازى است. سميت نانو ذرات مختلف در بــدن انسـان و جانوران آزمايشگاهى به دفعـات گَزارش شـده اسـت (IV)

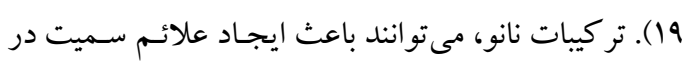

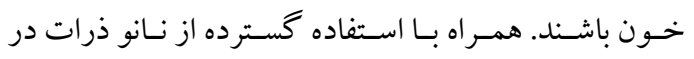
زمينه هاى مختلف، انسان خواسته يا ناخواسته در معرض ايـن

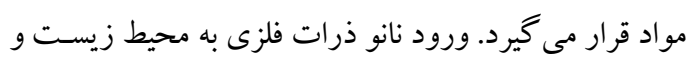
زنجيرههاى غذايى احتمال تداخل در سلامتى انسان و سـاير

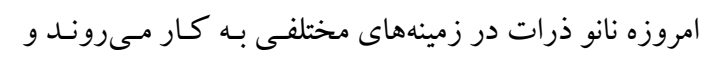

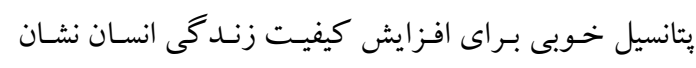
دادهاند. يثزوهش هاى زيادى در زمينه كـاربرد نـانو مـواد در مسائل يزشكى، بهداشتى، دارويى انجام يافته است (1). انواع مختلفسى از نـانو ذرات در ايـن زمينههــا مـورد بررسـى قـرار كرفتهاند كه يكى از بر كـاربرترين آنهـا، نـانوذرات اكسيد روى مى باشد كه به دليل هزينه يايين، نقشش هـاى متـوع در بلدن و تهيه راحت مورد توجه زيادى قرار گرفته اسـت (Y). نانوذرات اكسيد روى در زمينه هاى مختلف درمانى از جمله ديايت، ترميم زخم، ضدباكتريايى و سرطان بـه گرقتـه شـده

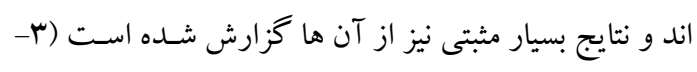

در جند سال اخير براى كاهش اثرات زيسـتمحيطى توليـد

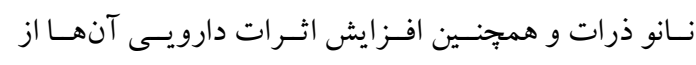

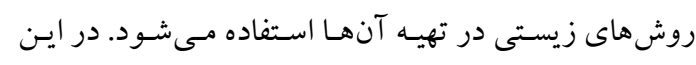
روشها از باكترىها، قارج هـا و حتى كياهـان در تهيـه ايسن مواد استفاده مى شـود (9). اسـتفاده از عصـاره كيـاهى بـراى

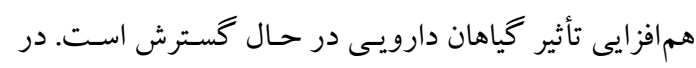

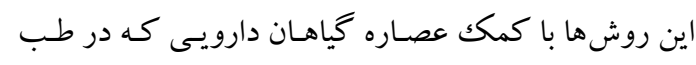
سنتى براى كنترل بيمارىهاى مختلفى استفاده مىشود، نـانو

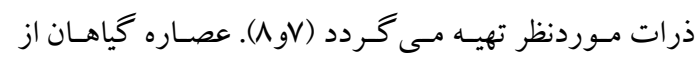
طريق مواد مؤثره مانند فلاونوئيدها، استروئيدها، الكالوئيـدها و غيره باعث كوجّك تر شدن اندازه نـانو داروهـا و درنتيجـه نفوذ بهتر و سريع تر به سلولها مى شوند و همبحنين تركيبات تهيه شـده بـا اثـر هـم افزايسى باعـث كنتـرل بهتـر بيمـارىهـا مى كردند (V). كياهان مختلفى در اين زمينه بـراى تهيـه نـانو داروهـا اسـتفاده شـده اسـت كـه از بـين آنهـا مـى تـوان بـه: charantia Amaranthus

caudatus اشـاره كـرد Silybum marianum،Momordica $(1 \cdot 9,9)$ مطالعــاتى در خصـــوص مـــواد مـــؤثره بـــركَ و ميـــوه Vaccinium arctostaphylos L بررسى متابوليت هاى اين كياه نشان داده است كه ميوههـاى

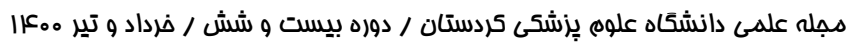


دارويى در اردبيل خريدارى شد. كيـت آنـاليز قند خـون ازئل

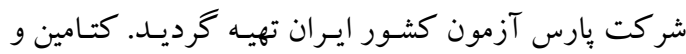
زايلزين از شر كت آلفاسان هند خريدارى شد.

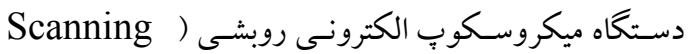
(Electron Microscopy, SEM با استفاده از دستگكاه مـدل(LEO 1430VP) سـاخت شـر كت LEO كشـور

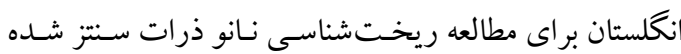

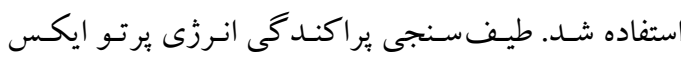
(Energy Dispersive X-Ray, EDX) خلموص و تر كيـب نـانوذرات توليـد شـده بـا همـان دسـتخاه

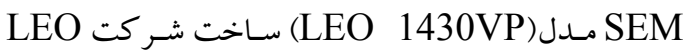
كشور آلمان مجهز به EDX انجام گرفتـ. ميكروسكوب

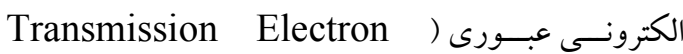
(Microscopy, TEM بـراى سـنش انـدازه نـانوذرات

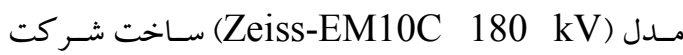
Zeiss

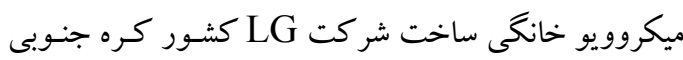
استفاده شد (1...W و (1). موشهاى آزمايشكاهى نر ويستار از خانه حيوانات دانشئاه

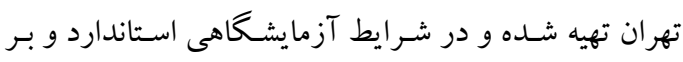

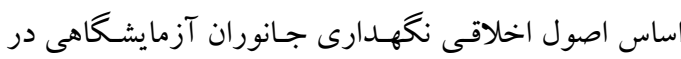
خانه حيوانات گروه زيست شناسى، دانشكده علوم، دانشكاه محقق اردبيلى نغهدارى شدند.

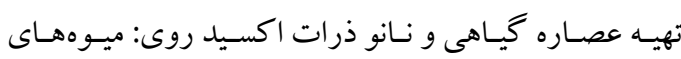

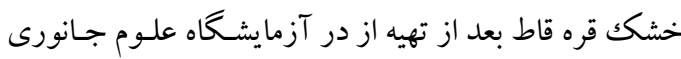
جندين با آب معمولى و سبس آب مقطر شستشو داده شـده

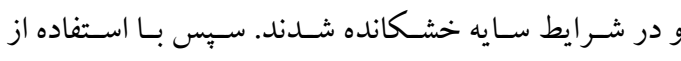

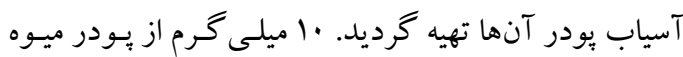

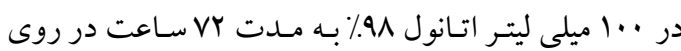

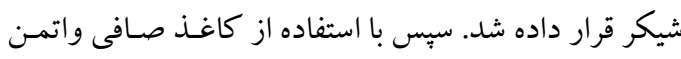

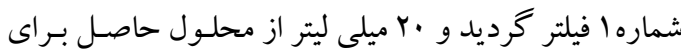

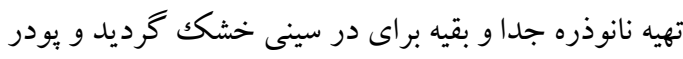

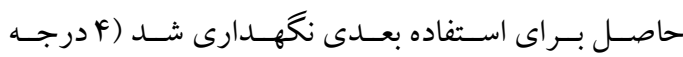
سانتى گراد)(Yr). نانو ذرات اكسيد روى به دو روش آبسى و
جانداران باعـث خواهــ شـــ (·r). ايـن مـواد مسىتوانتـد در اندامهاى مختلف بدن ماند قلب، ريه، كبد و كليه و ماهيجه

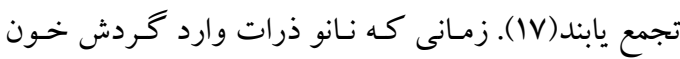
مى شوند با بروتئينهاى بلاسما و سيستم ايمنى بـدن مواجـه مى شوند. جذب اين مواد ممكن است از مسيرهـايى همانتــ

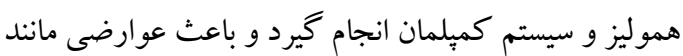
كاهش تعداد ياختههاى خونى، اثرات ضد ميتوزى، تحريك وني

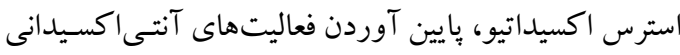

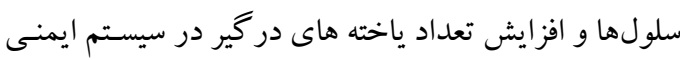
بدن است (Y)؛ لذا استفاده از نانو داروها بايـد بـا حساسيت داسيت

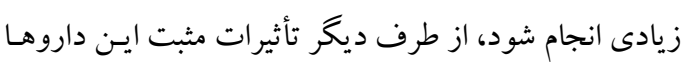

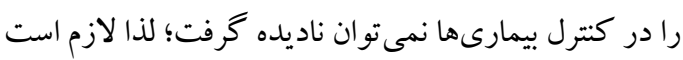
يزروهش هاى كاملى در جهت تعيين اثرات سـميتى ايـن نـانو

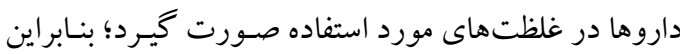
در اين مطالعه با توليد نانو داروهاى زيستى و مشخصـه يـابى آنها ضمن بررسى ميزان قند خون موشه هـاى ديـابتى تيمار

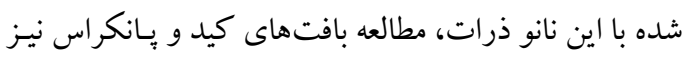

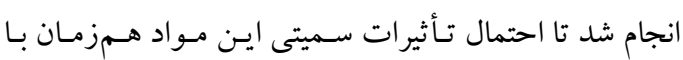

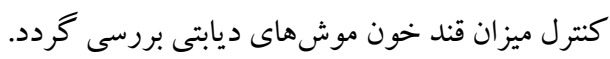

مواد و روشها در اين مطالعه تجربى تعداد ·rسر رت بـهصورت تصادفى

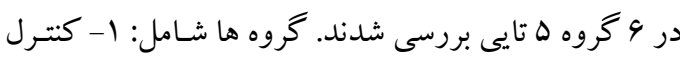

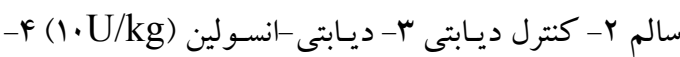

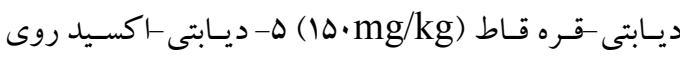

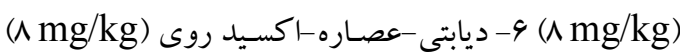
بودند. همه مو اد شيمايى با خلوص آزمايشكاهى بالابودنـد و بـدون نياز به خالصسازى بيشتر استفاده شدند. نيترات روى جهار بهار

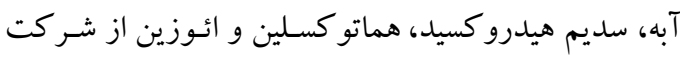

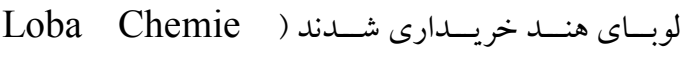
Company

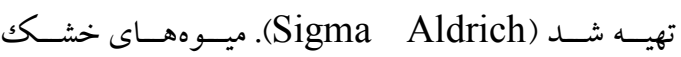
Vaccinium arctostaphylos L 
14

آناليزهاى لازم انجام شد. بِ از تهيه برشهاى بافتى از كبد

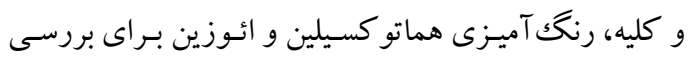

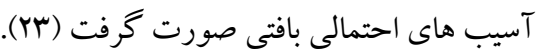

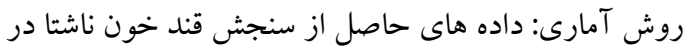

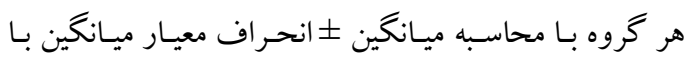

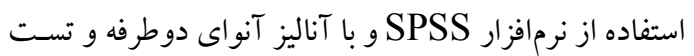

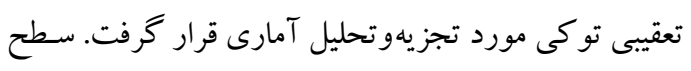

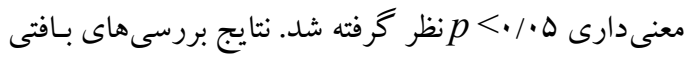
نيز به صورت كيفى توصيف و ززارش گرديد.

\section{يافته ها}

ويز گیى يابى نانو ذرات: ويز گَى يابى نانو ذرات سنتز شده بـه

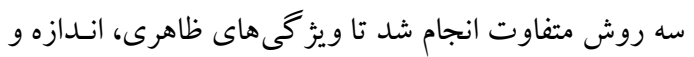

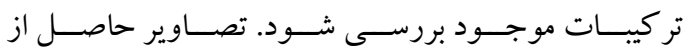
ميكروسكوبِ الكترونى روبشى نانو ذرات اكسيد روى تهيه

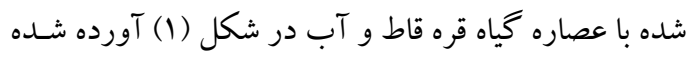
اسـت. در ايسن تصـوير شـكل كـروى نـانوذرات (اكــاملا)

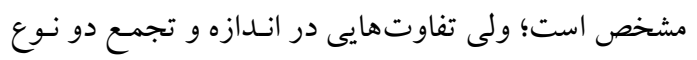

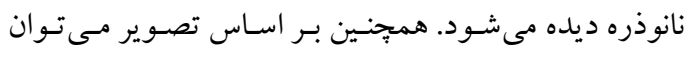

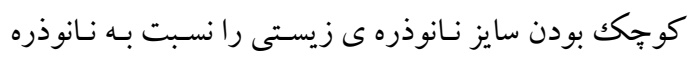
غير زيستى تشخيص داد و اين مطلب بيانخر حضور تر كيبات آلى در سطح نانوذره كه مـانع تجمـع و افز ايش حجـم نـانو

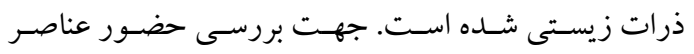

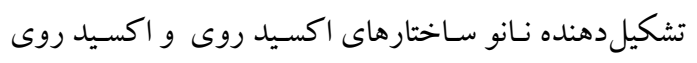

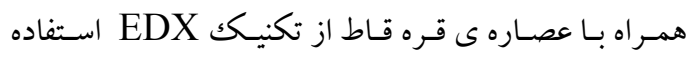

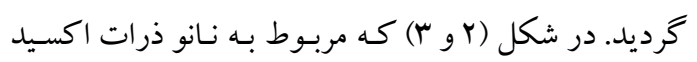

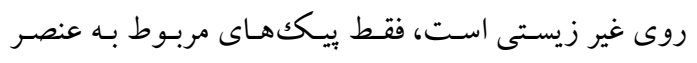

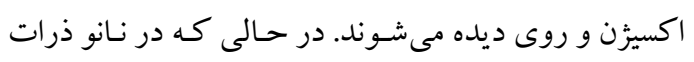

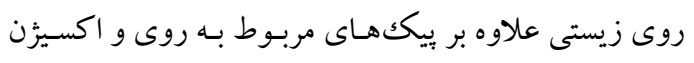

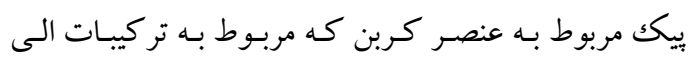

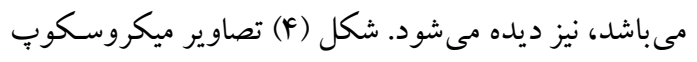

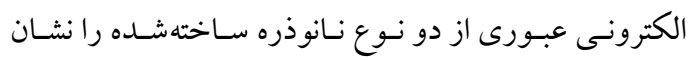

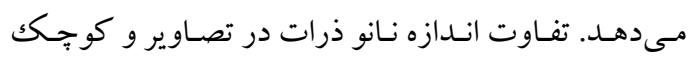
بودن نانوذره زيستى به طور مشخص ديده مى شود.
زيستى تهيه شدند. در روش زيستى ·r ميلى ليتر از عصـاره و

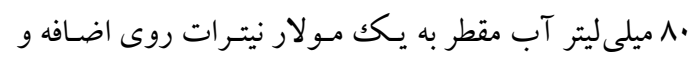

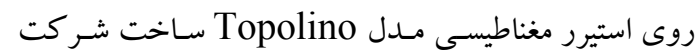

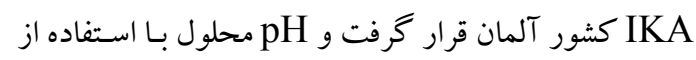

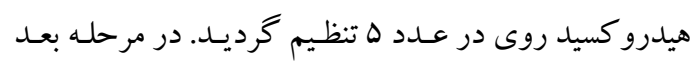

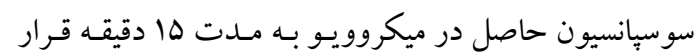
كرفت و بعد از سانتريفيوز ساخت شر كت Kubota كشور

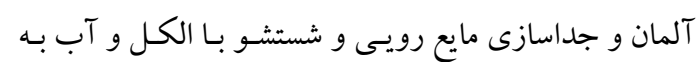

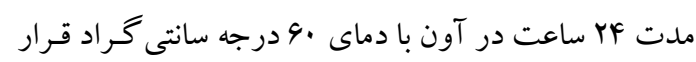

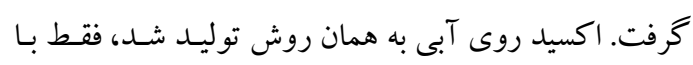

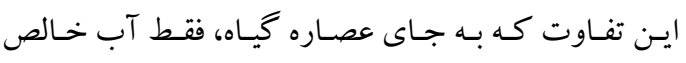
استفاده شد (F). القاى ديابت و گرووبندى: القـاى ديابـت بـا

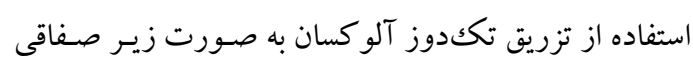

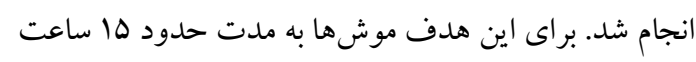

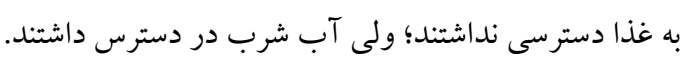

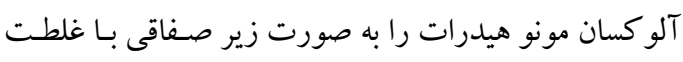

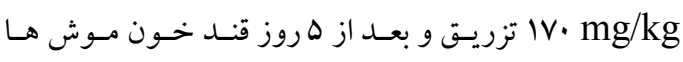

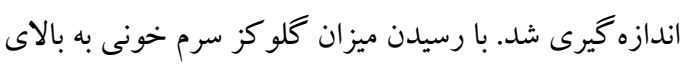

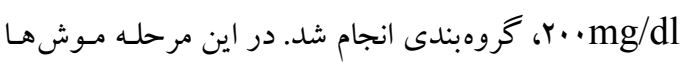

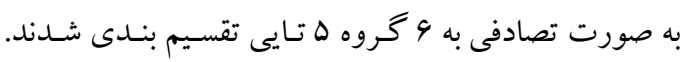
كروه اول: موشهاى سالم غير ديابتى كه در طول دوره سرم

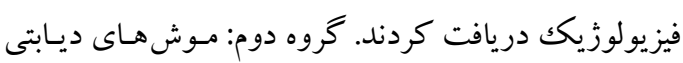

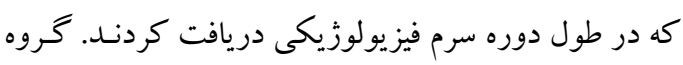

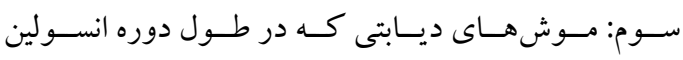
(1) ( U/kg)

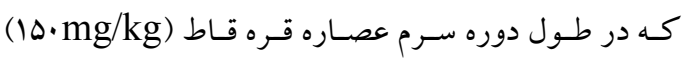
دريافت كردند. گروه ينجم: موشهاى ديابتى كه در طور

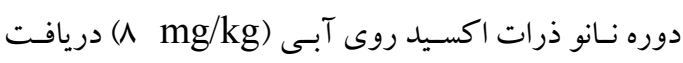

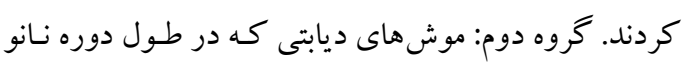
ذرات اكسيد روى زيستى (^ (^ mg/kg) دريافت كردند.

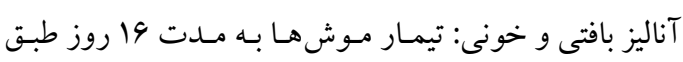

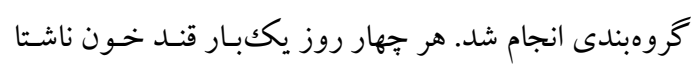

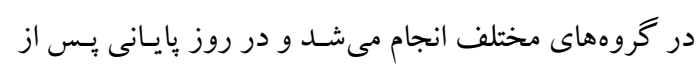

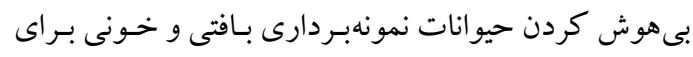


نانوذرات اكسيد روى نشـان داد كـه هرجند ايـن تر كيبـات

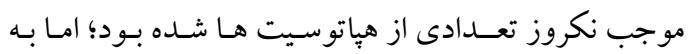
صورت خيلى جزئى از خروه ديابتى دريافت كننده انسولين

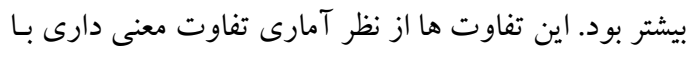

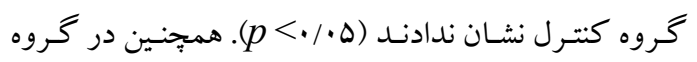

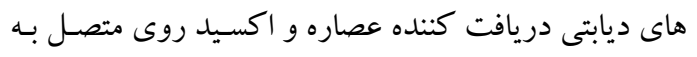

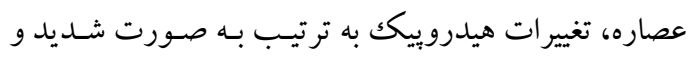

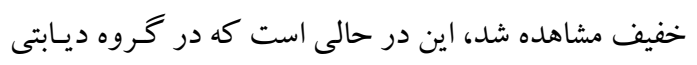

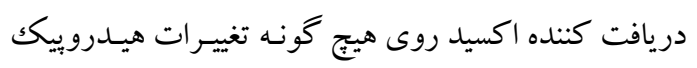

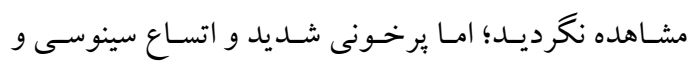

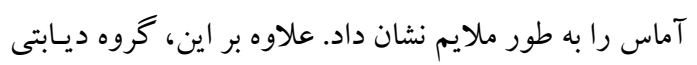

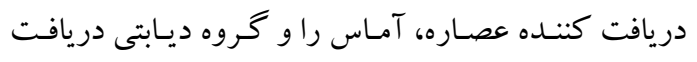

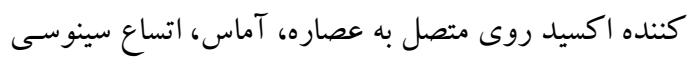

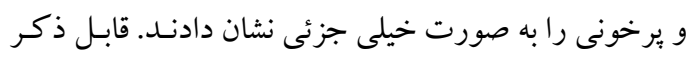

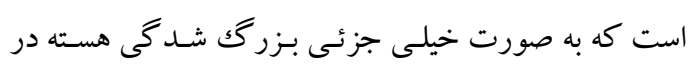

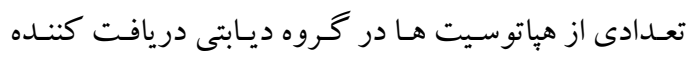
نانوذره اكسيد روى مشاهده ترديد.

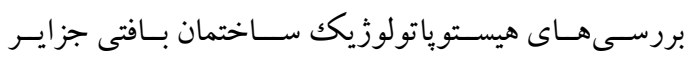

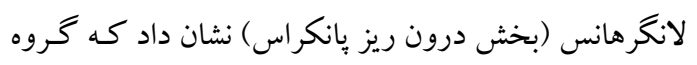

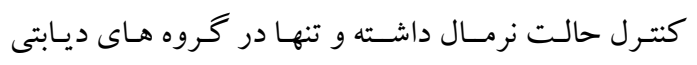

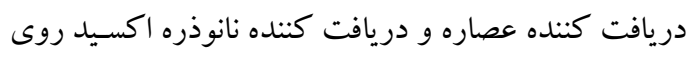

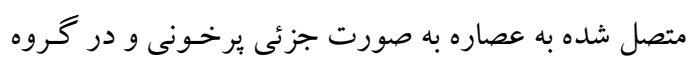

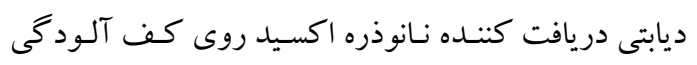

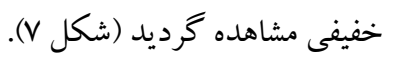

آناليز قند خون:

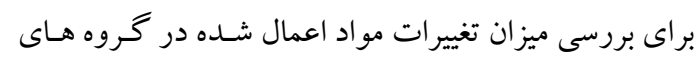
تيمار شده نسبت به كروه ديابتى كنترل ميزان قند خون ناشتان

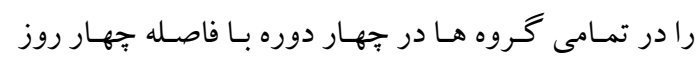

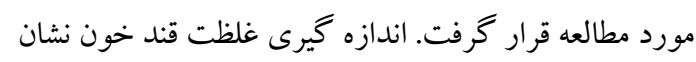

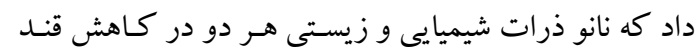

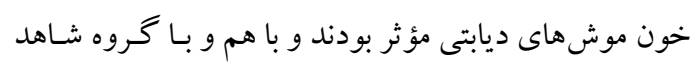

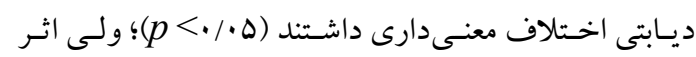

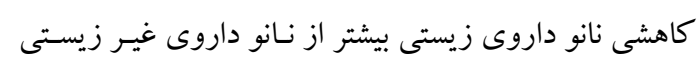

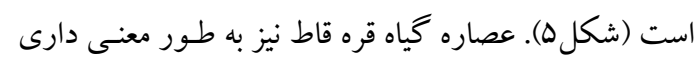

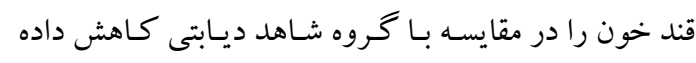

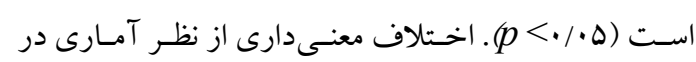

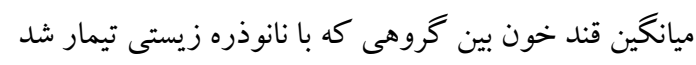

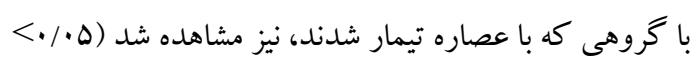

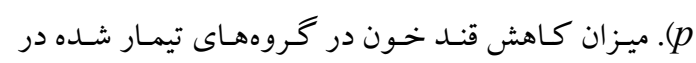
روزهاى مختلف نمونهبردارى حالت منظمى نداشته؛ ولى در كل نسبت به روز جهارم نمونسبـردارى در تمامى گحروههـا

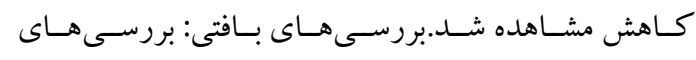

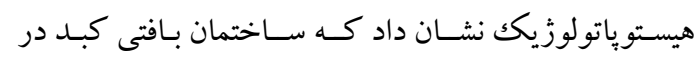

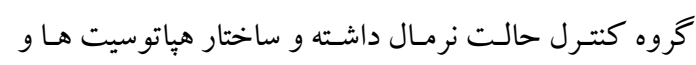

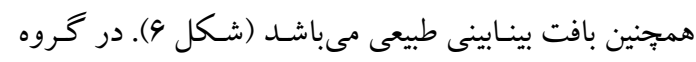

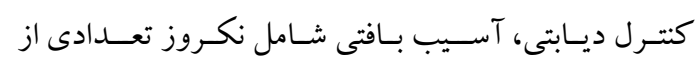

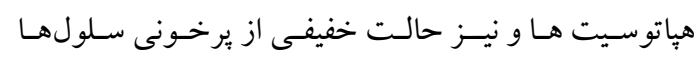
مشاهده شد. مطالعه حاضر ميز ان آسـيب وارده بـهـ ســاختار بافتى كبد در سـاير گروههاى موردمطالعه را نيز نشـان داد. در گروهى كه همزمان با ديابـ، انسولين دريافت كر كرده

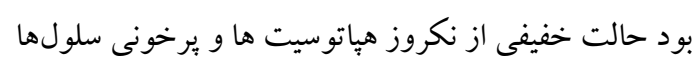

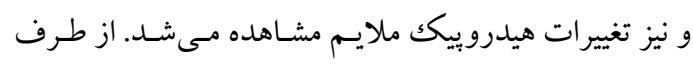

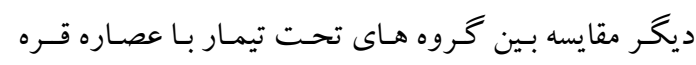

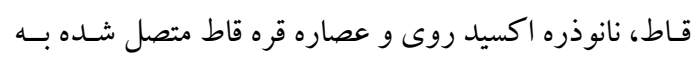




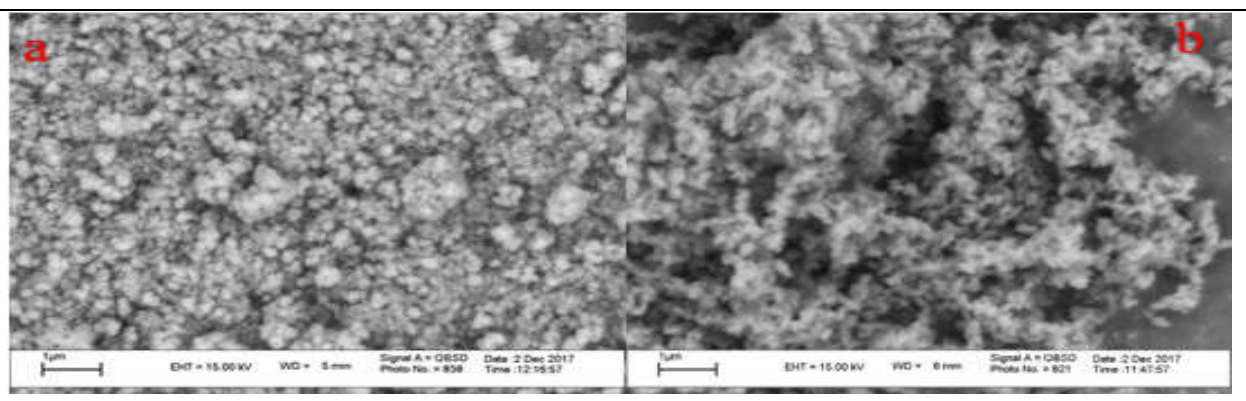

شكل 1. تصاوير ميكروسكوب الكترونى روبشى (SEM) از نانو ذرات سنتز شدهى اكسيد روى زيستى (a) و اكسيد روى (b). شكل ظاهرى كروى (b) رواتر

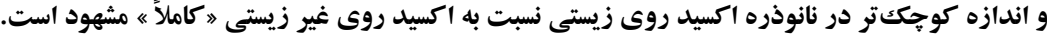

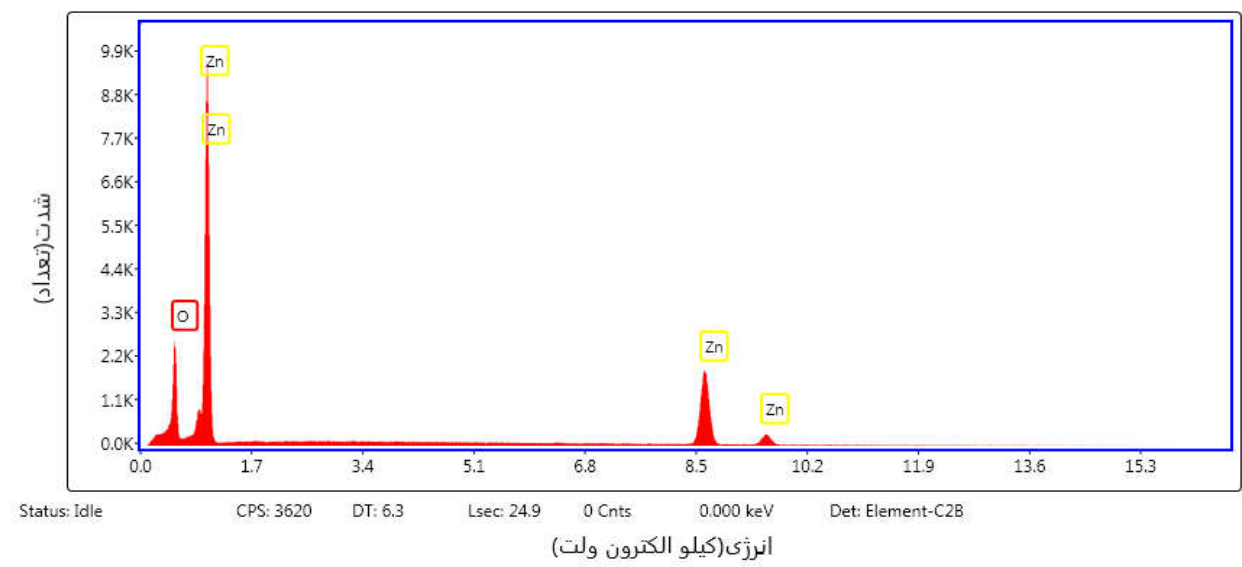

شكل r. طيفسنجى يراش انرخى يرتوX (EDX). عناصر تشكيلدهنده نانوذره اكسيد روى غير زيستى را نشان مىدهد. نتايج نشان دهنده حضور عناصر روى و اكسيثن در نانوداروى سنتز شده مى باشد.

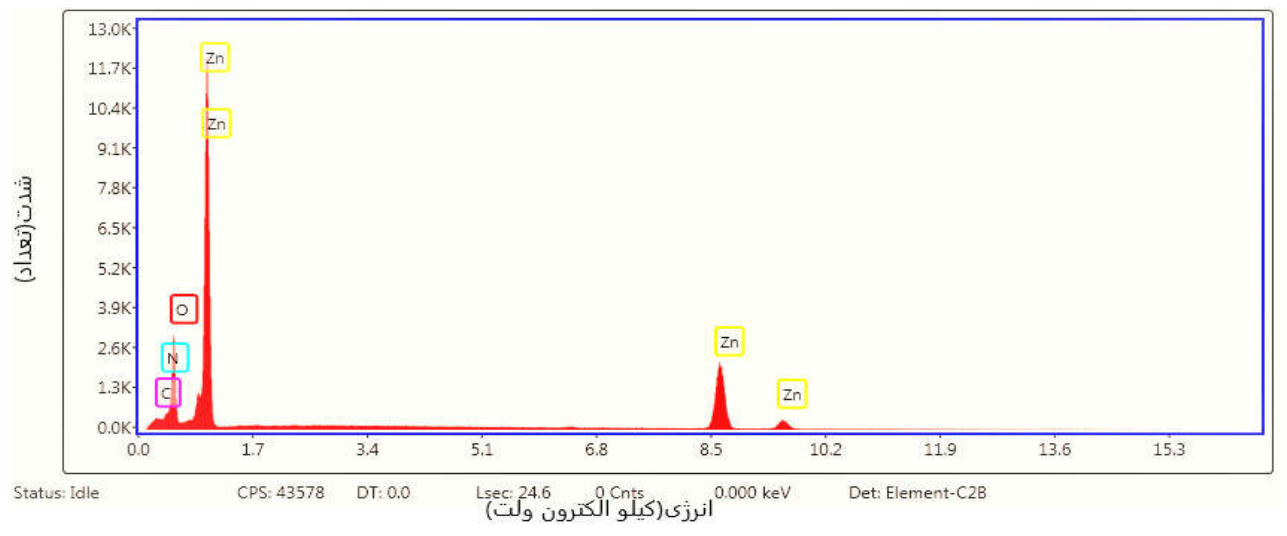

شكل r. طيفسنجى يراش انرخى يرتو XX) (EDX). عناصر تشكيلدهنده نانوذره اكسيد روى زيستى را نشان مىدهد. علاوه بر عناصر روى و اكسيزن، وجود عناصر كربن و نيتروزن نشانه حضور تر كيبات الى در سطح نانوذره است. 


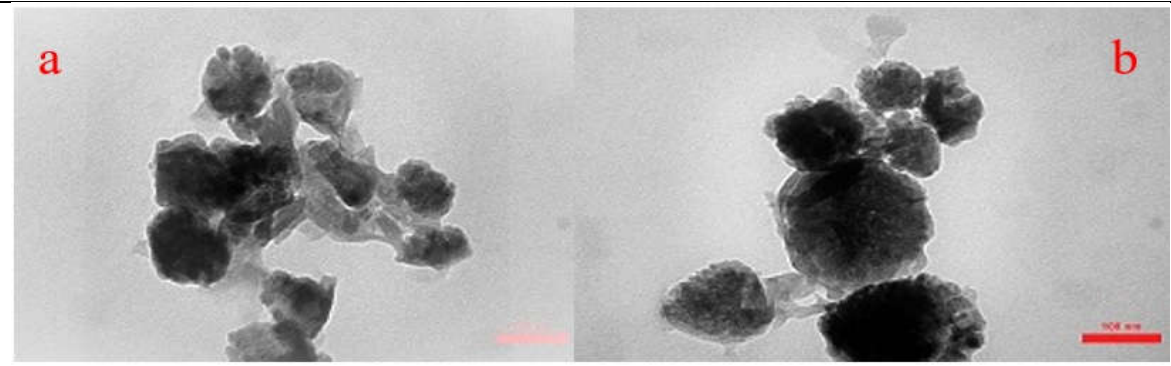

شكل f. تصوير ميكروسكوب الكترونى عبورى (TEM) از نانو ذرات ستتز شده در مقياس · • ا نانو متر اكسيد روى زيستى (a) و

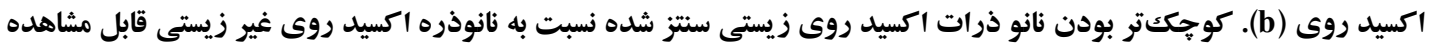
است.

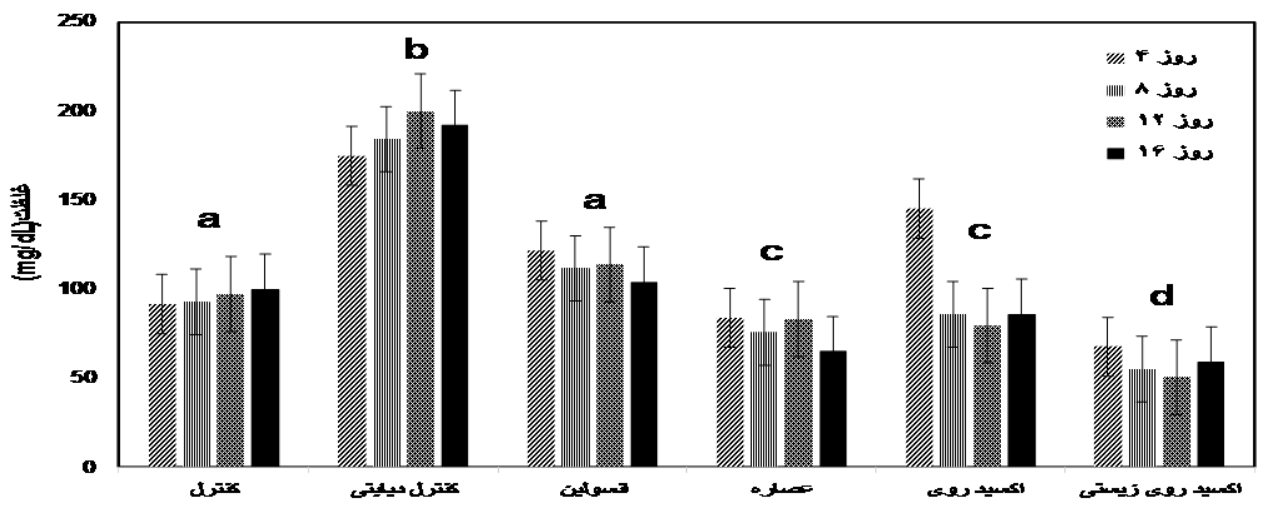

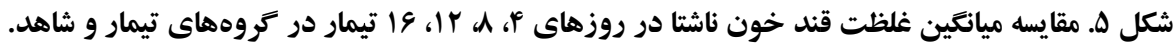

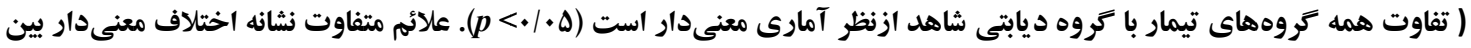

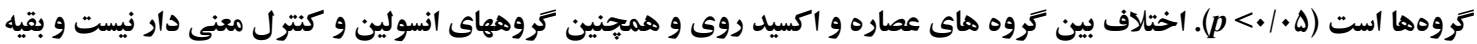
كروه ها با هم اختلاف معنى دار دار دارند. نكروذ هياتوسيت

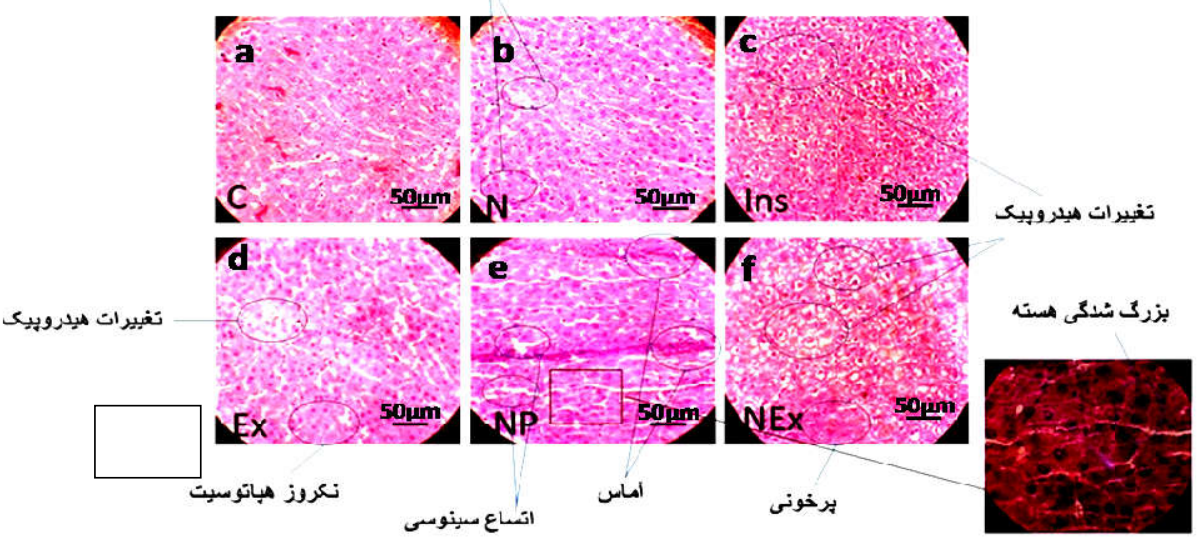

شكل \&. ساختمان ميكروسكويى بافت كبد در كروههاى مورد مطالعه رنك آميزى شده با هماتو كسيلين -ائوزين جهت نشان دادن

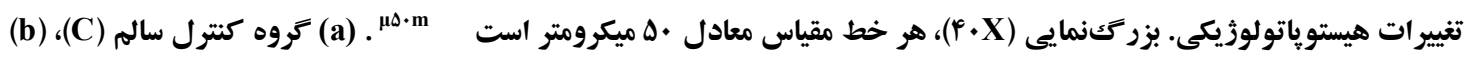

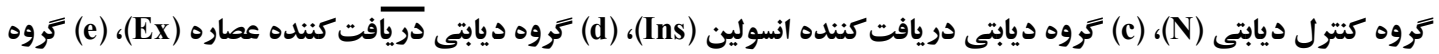

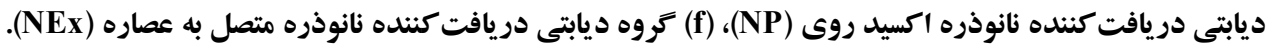




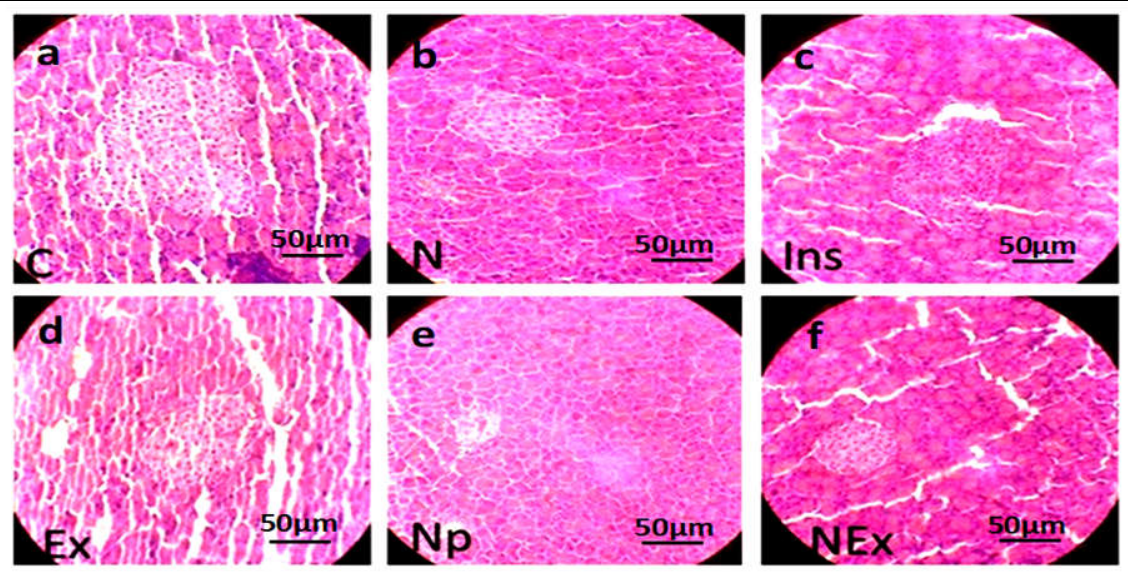

شكل Y. ساختمان ميكروسكويى بافت یانكراس در كروههاى موردمطالعه رنك آميزى شده با هماتو كسيلين-ائوزين جهت نشان

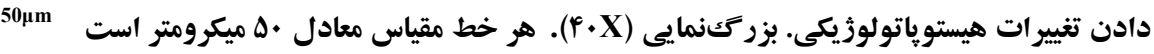

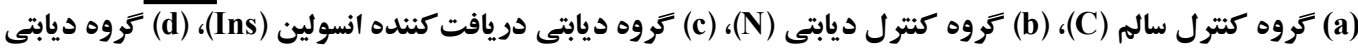

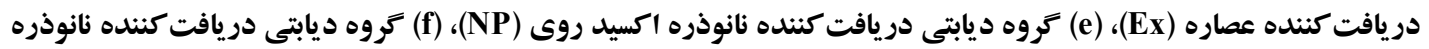
متصل به عصاره (NEx).

نقش غير قابل انكار يون هاى روى در عملكرد انسولين و نيز

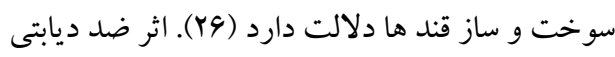
نانو ذرات ساخته شده به روش زيستى از جنبه ديخرى هم

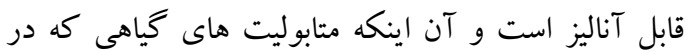
زمان ساخت باعث كاهش در يون هاى روى شده اند داراى إنى

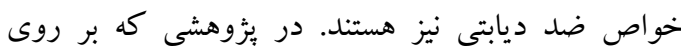

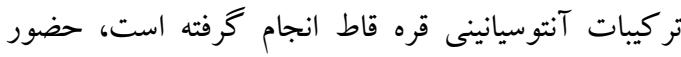

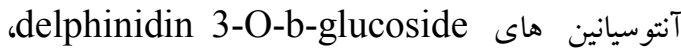
malvidin 3-O- g petuning 3-O-b-glucoside b-glucoside در عصاره اين گياه گزارششده است

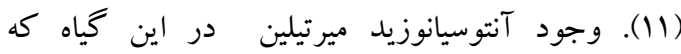
مكانيسمى مشابه انسولين دارد يكى از علل ويز گلى درمانى

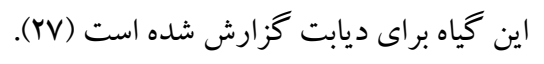

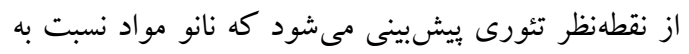
تركيبات ميكرو، به علت فعاليتهاى سطحى بالا و امكان

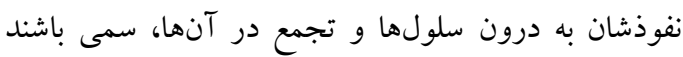

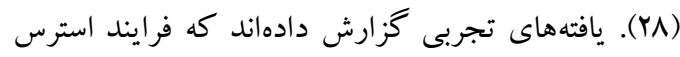
اكسيداتيو مىتواند نقش كليدى در القاى سميت سلولى لئى

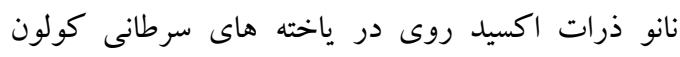
انسانى باشد (Yq). مصرف غلظت بالاى نانو ذرات اكسيد روى دريد
در اين مطالعه نانو ذرات اكسيد روى به دو روش غير زيستى و زيستى توليدشده و مورد بررسى قرار گرفتند و در ادامه علاوه بر مطالعه اثر درمانى آنها بر روى موشهاى ديابتى،

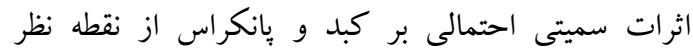
بافتشناسى بررسى شد. در الكوهاى EDX, SEM و لرغير TEM دليل محكمى بر صحت سنتز و حضور ZnO در هر بر برى

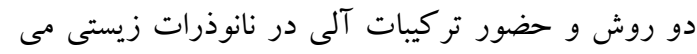
باشد. اثر كاهشى قند خون در گروه تيمار شده با نانو ذرات زيستى به طور معنىدارى مشهود بود و اين مىتواند مربوط به اثر هم افرايى تركيبات فلاونوئيدى عصاره و اكسيد روى باشد (Y). در نتايج يُوهشى در زمينه تأثيرات نانو ذره در بيمارى ديابت، به القاى بيان بعضى زنهاى مرتبط با اين

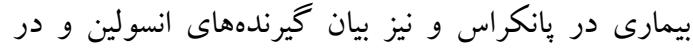

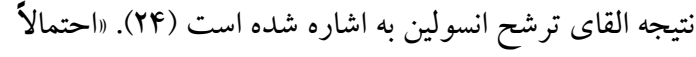

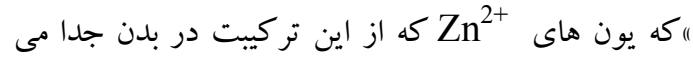
شود در مسير ترشح انسولين در پانكراس نقش دارند،

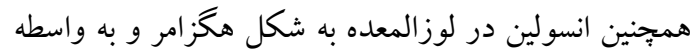

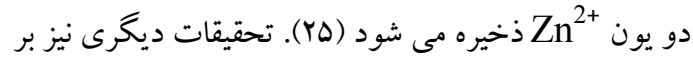


PI ابوالفضل بايراهى

اثرات بافتى معنىدارى گزارش نشد. اين نتيجه بيانخر اين است كه نانو ذرات در غلظتهاى بايين عليرغم تأثيرات

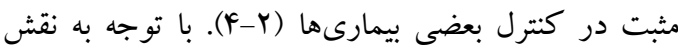
دارورسانى آنها، در عملكرد بافتهاى بدن اختلال ايجاد

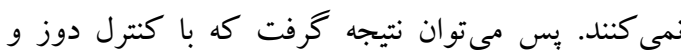

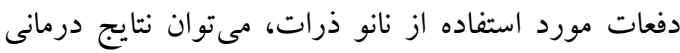
قابل توجهى از اين مواد به دست آورد و ميزان اثرات جانبى احتمالى را كاهش داد.

\section{نتيجه كيرى}

بافتهاى حاصل از اين بُزوهش نشان داد كه استفاده از علوم

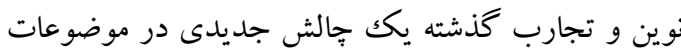
مختلف علمى، ازجمله يزشكى و داروسازى ايجاد كرده

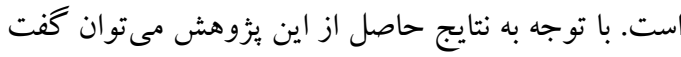
كه نانو ذرات بيولوزيكى سنتز شده با عصاره ميوه قره قاط

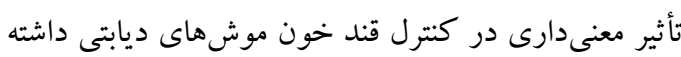

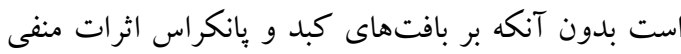

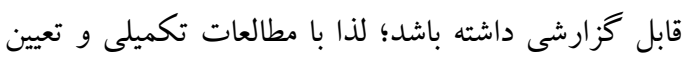
غلظت بهينه از نانو ذرات زيستى در كنترل و درمان بيمارى هاى مختلف قدم هاى بزركى برداشت.

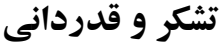

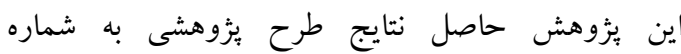
ه و و فناورى دانشكاه محقق اردبيلى و كد اخلاق به شماره

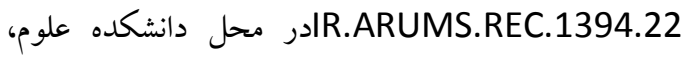
كروه زيستشناسى انجامشده است؛ لذا نويسند كان از واحد

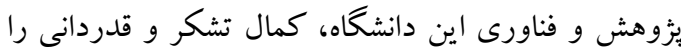

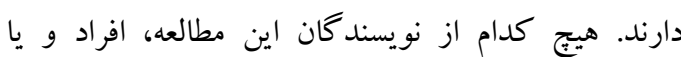
دستخاه ها تعارض منافعى براى انتشار اين مقاله ندارند.
روى و تركيبات حاوى آن از طريق دهانى عموماً، باعث

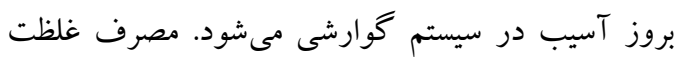
بالايى از نانو ذرات اكسيد روى به مدت هندين ماه مىتواند منجر به آنمى، نارسايى بانكراس و كاهش لييد

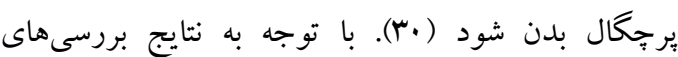

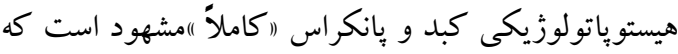
غلظت مورد استفاده از نانو ذرات سنتز شده به روش زيستى عليرغم داشتن خاصيت ضد ديابتى، اثرات سميتى معنى دارى در هيج كدام از بافتهاى كبد و يانكراس نداشته است؛ ولى نانو ذرات غير زيستى تهيه شده در بافت كبد بر خلاف نانو ذرات زيستى اثرات مخرب داشته درصورتى كه در بافت بِانكراس هيج عارضه بافتى ناشى از تيمار با نانو

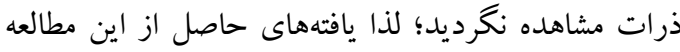
نشان داد كه نانو ذرات اكسيد روى تهيهشده با عصاره اتانولى ميوه قره قاط اثرات مثبتى در حفاظت از بافت هاى كبد و بانكراس در موشهاى ديابتى داشته است. با توجه به اينكه رويكردهاى جديد مطالعات بالينى به استفاده از عصاره گياهان دارويى در حال گسترش است، گياهان

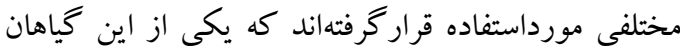
قره قاط مى باشد. قره قاط با داشتن اثرات ضدالتهابى و

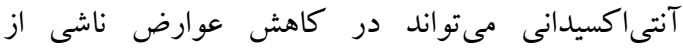

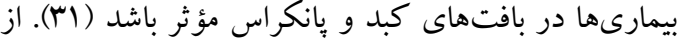
روشهايى كه (اخيراً) براى افزايش اثرات اين تر كيبات در بافت زنده به كار مىرود، ساخت نانو مواد فلزى مانند

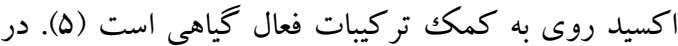
مطالعات مختلفى اثرات حفاظتى گياهان دارويى به علت نالت دارا بودن تركيبات مختلف فلاونوئيدى، آنتوسيانينى و فنولى بر بافتهاى مختلفى مانند كبد، بانكراس و كليه

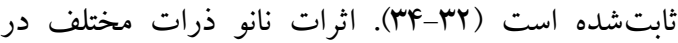
بافتهاى بدن نيز بررسى شده و به علت سايز كوجك و نانويى آنها و نفوذ راحت به سلولها، آسيبهاى جدى در

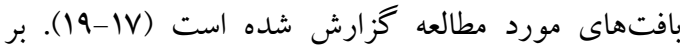
خلاف گزارشهايى كه در خصوص تأثيرات منفى و آسيبرسان نانو ذرات بر بافتهاى زنده در اين يزوهش

هجله علمى دانشكاه علوه ָِزشكى كردستان / دوره بيست و شش / ذرداد و تِير •ع|| 
1. Bayrami A, Shirdel A, Rahim Pouran S, Mahmoudi F, Habibi-Yangjeh A, Singh R, et al. Co-regulative effects of chitosan-fennel seed extract system on the hormonal and biochemical factors involved in the polycystic ovarian syndrome. Mater Sci Eng C. 2020;117:11351.

2.Bayrami A, Haghgooie S, Mohammadi Arvanag F, Rahim Pouran S, Habibi-Yangjeh A. Synergistic antidiabetic activity of $\mathrm{ZnO}$ nanoparticles encompassed by Urtica dioica extract. Adv Powder Technol. 2020;31(5):2110-2118.

3.Rahim Pouran S, Bayrami A, Mohammadi Arvanag F, Habibi-Yangjeh A, Darvishi Cheshmeh Soltani R, Singh R, et al. Biogenic integrated $\mathrm{ZnO} / \mathrm{Ag}$ nanocomposite: Surface analysis and in vivo practices for the management of type 1 diabetes complications. Colloids Surf B. 2020;189:110878.

4.Bayrami A, Ghorbani E, Rahim Pouran S, Habibi-Yangjeh A, Khataee A, Bayrami M. Enriched zinc oxide nanoparticles by Nasturtium officinale leaf extract: Joint ultrasoundmicrowave-facilitated synthesis, characterization, and implementation for diabetes control and bacterial inhibition. Ultrason Sonochem. 2019;58:104613.

5.Mohammadi-Aloucheh R, Habibi-Yangjeh A, Bayrami A, Latifi-Navid S, Asadi A. Enhanced anti-bacterial activities of $\mathrm{ZnO}$ nanoparticles and $\mathrm{ZnO} / \mathrm{CuO}$ nanocomposites synthesized using Vaccinium arctostaphylos L. fruit extract. Artif Cells Nanomed Biotechnol. 2018:1-10.

6.Mohammadi-Aloucheh R, Habibi-Yangjeh A, Bayrami A, Latifi-Navid S, Asadi A. Green synthesis of $\mathrm{ZnO}$ and $\mathrm{ZnO} / \mathrm{CuO}$ nanocomposites in Mentha longifolia leaf extract: characterization and their application as anti-bacterial agents. J Mater Sci Mater Electron. 2018;29(16):13596-605.

7.Agarwal H, Venkat Kumar S, Rajeshkumar S. A review on green synthesis of zinc oxide nanoparticles - An eco-friendly approach. Res Eff Tech. 2017;3(4):406-13.

8.Kuppusamy P, Yusoff MM, Parine NR, Govindan N. Evaluation of in-vitro antioxidant and antibacterial properties of Commelina nudiflora L. extracts prepared by different polar solvents. Saudi J Biol Sci. 2015;22(3):293-301.

9.Jeyabharathi S, Kalishwaralal K, Sundar K, Muthukumaran A. Synthesis of zinc oxide nanoparticles (ZnONPs) by aqueous extract of Amaranthus caudatus and evaluation of their toxicity and antimicrobial activity. Mater Lett. 2017;209:295-8.

10.Shanker K, Naradala J, Mohan GK, Kumar GS, Pravallika PL. A sub-acute oral toxicity analysis and comparative in vivo anti-diabetic activity of zinc oxide, cerium oxide, silver nanoparticles, and Momordica charantia in streptozotocin-induced diabetic Wistar rats. RSC Adv. 2017;7(59):37158-67.

11.Nickavar B, Amin G, H Salehi-Sormagi M. Anatomical study on Vaccinium arctostaphylos L. Die Pharmazie. 2003;58:274-8.

12.Sepehrifar R, Hasanloo T. Polyphenolics, Flavonoids and anthocyanins content and antioxidant activity of Qare-Qat (Vaccinium arctostaphylos L.) from different areas of Iran. J Med Plants. 2010;1(33):66-74.

13.Feshani AM, Kouhsari SM, Mohammadi S. Vaccinium arctostaphylos, a common herbal medicine in Iran: molecular and biochemical study of its antidiabetic effects on alloxandiabetic Wistar rats. J Ethnopharmacol. 2011;133(1):67-74.

14.Wang Q, Zhang X, Fang L, Guan Q, Guan L, Li Q. Prevalence, awareness, treatment and control of diabetes mellitus among middle-aged and elderly people in a rural Chinese population: A cross-sectional study. PloS one. 2018;13(6):e0198343. 
ابوالفضل بايراهى

15.Ebrahimi H, Emamian MH, Hashemi H, Fotouhi A. High Incidence of Diabetes Mellitus Among a Middle-Aged Population in Iran: A Longitudinal Study. Can J Diabetes. 2016;40(6):570-5.

16.Agarwal V, Kochhar A, Sachdeva R. Sensory and nutritional evaluation of sweet milk products prepared using stevia powder for diabetics. Stud EthnoMed. 2010;4(1):9-13.

17. Sheydaei P, Bayrami A, Azizian Y, Parvinroo S. Study on the toxicity effects of zinc oxide nanoparticles on hematological and serum parameters in mice. J Arak Uni Med Sci. 2017;19(10):39-47.

18.Arbabi S, Bayrami A, Sheidaii P. An Investigation of the toxicity of zinc oxide and titanium oxide nanoparticles on some liver enzymes in male mice. J Rafsanjan Univ Med Sci. 2017;16(7):633-44.

19. Shydaei P, Bayrami A, Arbabi S. Evaluation the toxicity of Titanium dioxide nanoparticles on hematological and biochemical parameters in mice. Anim Res J. 2019; 3(4):472-82.

20. Gustafson HH, Holt-Casper D, Grainger DW, Ghandehari H. Nanoparticle Uptake: The Phagocyte Problem. Nano Today. 2015;10(4):487-510.

21. Ben-Slama I, Mrad I, Rihane N, EL Mir L, Sakly M, Amara S. Sub-acute oral toxicity of zinc oxide nanoparticles in male rats. J Nanomed Nanotechnol. 2015;06.

22. Servatyari K, Ahmadi A, Kashefi H, Manbari M N, Rostami A, Moulodi M R. The effect of hydroalcoholic extract of Medicago sativa on liver function tests, blood biochemical factors and coagulation system in male rats. Sci J Kurdistan Univ Med Sci. 2017; 21(6):1626.

23. Moloudi R, Nabavizadeh F, Nahrevanian H, Hassanzadeh G. Effect of different doses of GLP-2 (Teduglutide) on acute esophageal lesion due to acid-pepsin perfusion in male rats. Peptides. 2011;32(10):2086-90.

24.Bala N, Saha S, Chakraborty M, Maiti M, Das S, Basu R, et al. Green synthesis of zinc oxide nanoparticles using Hibiscus subdariffa leaf extract: effect of temperature on synthesis, anti-bacterial activity and anti-diabetic activity. RSC Advances. 2015;5(7):4993-5003.

25.Dodson G, Steiner D. The role of assembly in insulin's biosynthesis. Curr Opin Struct Biol. 1998; 82(0):189-194.

26.Arquilla ER, Packer S, Tarmas W, Miyamoto S. The effect of zinc on insulin metabolism. Endocrinol. 1978; 103(4):1440-9.

27.Murray M. Bilberry (Vaccinium myrtillus). Textbook of Natural Medicine, 2013;10801085.

28.Xiong D, Fang T, Yu L, Sima X, Zhu W. Effects of nano-scale TiO2, ZnO and their bulk counterparts on zebrafish: acute toxicity, oxidative stress and oxidative damage. Sci Total Environ. 2011;409(8):1444-52.

29.De Berardis B, Civitelli G, Condello M, Lista P, Pozzi R, Arancia G, et al. Exposure to $\mathrm{ZnO}$ nanoparticles induces oxidative stress and cytotoxicity in human colon carcinoma cells. Toxicol Appl Pharmacol. 2010;246(3):116-27.

30.Wang C, Zhang SH, Wang PF, Hou J, Zhang WJ, Li W, et al. The effect of excess Zn on mineral nutrition and antioxidative response in rapeseed seedlings. Chemosphere. 2009;75(11):1468-76.

31. Huang W, Yan Z, Li D, Ma Y, Zhou J, Sui Z. Antioxidant and anti-inflammatory effects of blueberry anthocyanins on high glucose-induced human retinal capillary endothelial cells. Oxid Med Cell Longev. 2018;2018:1-10.

32. Rafiey Z, Jalili F, Sohrabi M, Salahshoor, Mohammad reza, Jalili C. Effects of Hydroalcoholic Extract of Falcaria Vulgaris on Pancreas Tissue in Streptozotocin-induced Diabetic Rats. Iran J Endocrinol Metab. 2017;19(2):91-8.

هجله علمى دانشكاه علوه يِزشكى كردستان / دوره بيست و شش / ذرداد و تير م.ع|| 
عار دطالعم اثرات بافتى نانو ذرات...

33. Mohammadifar M, Behnam M, Talaei SA, Khamechian T, Mehran M, Taghizadeh M. Evaluation effect of silybum marianum, Cynara Scolymus L. and Ziziphus jujube Mill. combination extract on non-alcoholic fatty liver in rats. Iran $\mathbf{J}$ Endocrinol Metab. 2018;19(6):410-8.

34.Vargas F, Romecin P, Garcia-Guillen AI, Wangesteen R, Vargas-Tendero P, Paredes MD, et al. Flavonoids in Kidney Health and Disease. Front Physiol. 2018;9:394. 